\title{
Prevalence and treatment of vitamin D deficiency in children on anticonvulsant drugs
}

\author{
J. SILVER, T. J. DAVIES, EMELIA KUPERSMITT, M. ORME, AVIVA PETRIE, \\ and F. VAJDA* \\ From the Royal Postgraduate Medical School, London; and Queen Mary's Hospital, Carshalton, Surrey
}

Silver, J., Davies, T. J., Kupersmitt, E., Orme, M., Petrie, A., and Vajda, F. (1974). Archives of Disease in Childhood, 49, 344. Prevalence and treatment of vitamin $D$ deficiency in children on anticonvulsant drugs. Bone metabolism was studied in a group of adolescent epileptic children given anticonvulsant drugs and compared with a matched group of nonepileptic children living in the same institutional environment. Biochemical evidence of vitamin $\mathrm{D}$ deficiency was more common in treated children than in controls, and 3 out of 60 children taking anticonvulsants had radiological evidence of rickets. The signs of vitamin $\mathrm{D}$ deficiency could not be corrected by giving $5 \mu \mathrm{g}$ ( $200 \mathrm{IU}$ ) cholecalciferol daily for 12 weeks, but disappeared after treatment with $75 \mu \mathrm{g}$ (3000 IU) cholecalciferol weekly for a further 12 weeks. Thus, in a residential home in southeast England the increased nutritional requirement for vitamin $\mathrm{D}$ caused by the administration of anticonvulsants to adolescent epileptic children was of the order of $10 \mu \mathrm{g}$ cholecalciferol per day. It is likely that all epileptic subjects on anticonvulsants have increased needs for vitamin D and we advise regular supplementation of their diets.

It is also shown that serum concentrations of $\gamma$-glutamyl transpeptidase, 5 'nucleotidase, and leucine aminopeptidase are raised in children taking anticonvulsants. It seems likely that this is caused by drug induction of membranebound enzymes in the liver.

The observations by Schmid (1967) and by Kruse (1968) of rickets and osteomalacia occurring in epileptic patients on long-term anticonvulsant therapy have been confirmed by Richens and Rowe (1970) and Hunter et al. (1971). It was suggested that anticonvulsants enhance the breakdown of vitamin $\mathrm{D}$ by inducing hepatic microsomal enzymes (Dent et al., 1970). This suggestion is now supported by both clinical and experimental evidence. First, Hahn et al. (1972) have shown that epileptic patients taking anticonvulsants regularly have lower concentrations of circulating 25-hydroxycholecalciferol than control subjects on similar diets. Secondly, in both rats and pigs it has been shown that the administration of phenobarbitone enhances the conversion of cholecalciferol to 25-hydroxycholecalciferol and increases the excretion of biliary metabolites (Silver et al., 1972a, b).

In view of these observations it has become

Received 8 October 1973.

*Present address: Department of Pharmacology and Therapeutics, Middlesex Hospital, London W1P 7PN. necessary to determine the requirements for dietary vitamin $D$ by subjects taking anticonvulsant drugs regularly. Such a study is of particular importance in Great Britain where foodstuffs are not fortified with vitamin $\mathrm{D}$ and where there has been a growing awareness of a latent deficiency of the vitamin among certain susceptible groups, especially immigrants (Holmes et al., 1973), adolescent children (Cooke et al., 1973), and the elderly (Gough, Lloyd, and Wills, 1964). In this paper we report a controlled study of the prevalence of rickets in epileptic adolescent children and its treatment with small doses of cholecalciferol.

\section{Material and methods}

Mentally subnormal epileptic children aged from 10 to 16 years who had been in long-stay wards of Queen Mary's Hospital for at least 2 years and who had been receiving phenobarbitone (mean $\pm \mathrm{SE} 65 \pm 7 \mathrm{mg} /$ day), primidone ( $485 \pm 54 \mathrm{mg} /$ day), or phenytoin $(120 \pm 11$ $\mathrm{mg} /$ day), or a combination of these drugs, were studied. They were compared with a group of children of similar age who had been resident for the same period of time in 
the same hospital wards, but who were not epileptic and who were not receiving any anticonvulsant drugs. The examination and venepuncture of control children as well as those with epilepsy was thought necessary on clinical as well as scientific grounds in view of the recent reports of rickets occurring among normal adolescent children in this country (Cooke et al., 1973).

The first study was carried out in January 1972. The children's nutritional status was assessed and venous blood was taken for haematological and biochemical measurements, described below. The results of these tests in children taking anticonvulsants were compared with those for children taking no drugs.

The second study was designed to assess the effect of supplementing the diet with a small dose of vitamin D daily. Half of the group of children on anticonvulsants and half of the control group were randomly allocated to receive $200 \mathrm{IU}(5 \mu \mathrm{g})$ cholecalciferol daily for 12 weeks. The other half of each group received a placebo preparation daily (Fig. 1). Crystalline cholecalciferol was dissolved in arachis oil base in a concentration of $2000 \mathrm{IU} / \mathrm{ml}$. $0.1 \mathrm{ml}$ aliquots of this solution were pipetted onto cubes of sugar which were then stored at $4{ }^{\circ} \mathrm{C}$. $0.1 \mathrm{ml}$ arachis oil on sugar lumps was used as the placebo preparation. Nursing staff gave the children their sugar lumps daily for 12 weeks. At the end of this period samples of venous blood were taken and biochemical and haematological measurements were made as before.

The third study was designed to assess the effect of feeding a large dose of vitamin $\mathrm{D}$ each week. 33 children receiving anticonvulsants were given 3000 IU $(75 \mu \mathrm{g})$ cholecalciferol orally in arachis oil each week for 12 weeks from October to December 1972. Blood was taken again from these children and from 32 control children not receiving drugs, in order to compare the serum measurements.

Chemical methods. Samples of venous blood were taken fasting, with stasis, from all patients on the same morning for each study. The packed cell volume of each sample was measured and serum or plasma was separated within 4 hours and stored under standard conditions before being assayed. Serum calcium, phosphate, alkaline phosphatase, urea, total protein, and albumin were measured by standard Auto-Analyzer techniques. Alkaline phosphatase isoenzymes were assessed by measurement of heat stability (Moss, Shakespeare, and Thomas, 1972). $\gamma$-Glutamyl transpeptidase was assayed by the spectrophotometric technique of Szasz (1969), 5'nucleotidase by the spectrophotometric method of Campbell (1962), and leucine amino peptidase by a fluorometric method (Peters, Müller, and de Duve, 1972). Serum and red cell folate concentrations and serum vitamin $B_{12}$ were measured using standard microbiological assays. Phenobarbitone and diphenyl hydantoin levels were measured using gas-liquid chromatographic techniques (MacGee, 1970). Primidone was measured as its active metabolite, phenobarbitone (Butler and Waddell, 1956). At the start of the study all patients were tested for circulating Australia antigen and 2 were found to be positive; these were excluded from subsequent studies.

Radiology. The wrists of selected children were $x$-rayed and the results assessed (Dr. F. H. Doyle, Department of Radiology, Royal Postgraduate Medical School).

Dietary assessment for vitamin $D$. The vitamin $\mathrm{D}$ content of the diet fed to the children in each ward was assessed by dietitians using standard tables (McCance and Widdowson, 1960).

Statistics. Statistical variations among the results were evaluated by Student's ' $t$ ' test.

\section{Results}

Study 1. Comparison of children taking anticonvulsants with controls. 59 children taking anticonvulsants were studied. There were 41 boys and 18 girls with a mean age of $14 \pm 0.3$ years and a mean weight of $31 \pm 2 \mathrm{~kg}$. They were

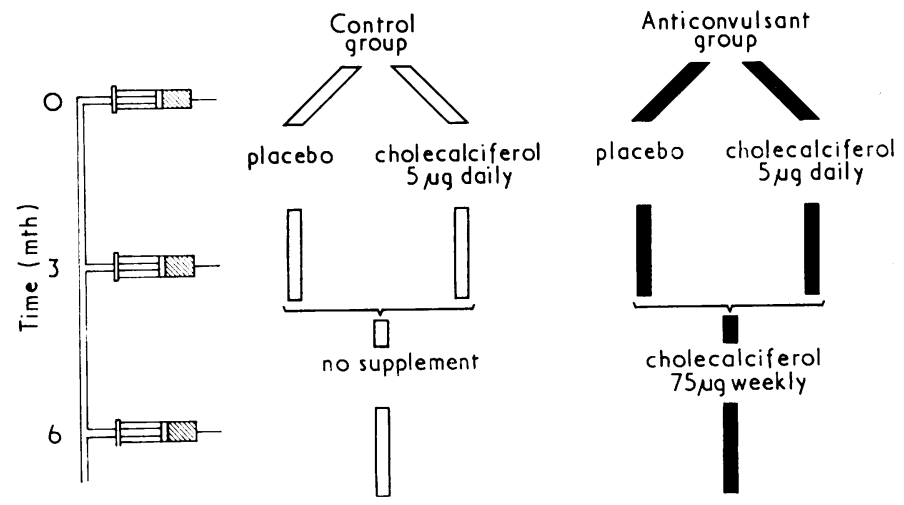

Fig. 1.-Diagrammatic representation of plan of study. 
compared with a group of 28 boys and 21 girls of mean age $14 \pm 0.4$ years and mean weight $30 \pm 2 \mathrm{~kg}$. In all respects other than the presence or absence of epilepsy, the two groups of children appeared to be well matched.

Vitamin $D$ intake. The control and epileptic children were in the same wards and were given the same diet. The average daily vitamin $\mathrm{D}$ content of the food given to the children was $85 \pm 10 \mathrm{IU} /$ day (mean \pm SEM), with a range of 58 to $200 \mathrm{IU} /$ day. These figures were obtained from an analysis of meals over a period of 2 weeks using standard tables (McCance and Widdowson, 1960) to estimate the amount of vitamin $D$. On fine days the children spent about 5 hours a day outdoors and only if it was very wet were they kept indoors all day.

Nutritional factors other than those related to bone disease (Table I). There was no difference in the mean values of total serum proteins, serum albumin, or vitamin $B_{12}$ between the two groups. The mean serum folate value was lower in children taking anticonvulsants (mean $4 \cdot 7 \pm 2 \cdot 5 \mathrm{ng} / \mathrm{ml}$ compared with $6 \cdot 6 \pm 2 \cdot 7 \mathrm{ng} / \mathrm{ml}, \mathrm{P}<0 \cdot 01$ ), but only 9 children had values of less than $3 \mathrm{ng} / \mathrm{ml}$ of whom 7 were on anticonvulsants. Though the serum folate values were lower in children on anticonvulsants, this difference was not reflected in values for packed cell volume, nor in the concentration of folic acid in red cells.

Serum calcium, phosphate, and alkaline phosphatase (Table I). The mean serum calcium values in control subjects $(5 \cdot 0 \pm 0 \cdot 2 \mathrm{mEq} / 1$.) and in children taking anticonvulsants $(4 \cdot 9 \pm 0 \cdot 3 \mathrm{mEq} / 1$.) were not significantly different, but the serum phosphate levels were lower in the group of children taking anticonvulsants $(2.4 \pm 0.4 \mathrm{mEq} / 1$.) than in control children $(2 \cdot 7 \pm 0.3 \mathrm{mEq} / \mathrm{l} ., \mathrm{P}<0.001)$ (Fig. 2). The mean serum alkaline phosphatase in children
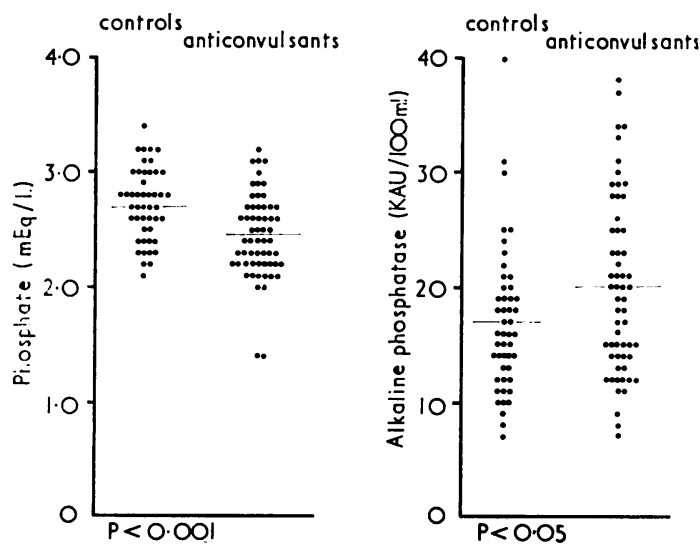

FIG. 2.-Serum phosphate and alkaline phosphatase (King-Armstrong units) in control children and children on anticonvulsant drugs.

taking anticonvulsants was $20 \pm 8 \mathrm{KAU} / 100 \mathrm{ml}$ compared with $17 \pm 6 \mathrm{KAU} / 100 \mathrm{ml}$ in controls $(P<0.05)$ (Fig. 2). It was shown that the bone isoenzyme of alkaline phosphatase predominated in the sera of all children whether or not they were taking anticonvulsants.

It was not possible to show significant differences between groups of children on anticonvulsants subdivided according to drug treatment or by plasma concentration of anticonvulsants. It appeared that children with a high level of circulating barbiturates $(>40 \mu \mathrm{g} / \mathrm{ml})$ had higher values of alkaline phosphatase and lower values of serum phosphate than those with lower barbiturate levels, but the differences did not reach statistical significance.

Circulating hepatic enzymes (5'nucleotidase, leucine aminopeptidase, $\gamma$-glutamyl transpeptidase). The mean serum values of the 'biliary tract' enzymes were significantly greater in children taking anti-

TABLE I

Haematology and serum proteins, calcium, phosphate, and alkaline phosphatase in study 1 (mean $\pm S D$ )

\begin{tabular}{|c|c|c|c|c|}
\hline & & Controls & Anticonvulsant group & $\mathbf{P}$ \\
\hline $\begin{array}{l}\text { Total protein } \\
\text { Albumin } \\
\text { Serum folic acid } \\
\text { Red cell folate } \\
\text { Vitamin } B_{12} \\
\text { Packed cell volume } \\
\text { Calcium } \\
\text { Phosphate } \\
\text { Alkaline phosphatase }\end{array}$ & $\begin{array}{l}(\mathrm{g} / 100 \mathrm{ml}) \\
(\mathrm{g} / 100 \mathrm{ml}) \\
(\mathrm{ng} / \mathrm{ml}) \\
(\mathrm{ng} / \mathrm{ml}) \\
(\mathrm{pg} / \mathrm{ml}) \\
(\%) \\
(\mathrm{mEq} / \mathrm{l} .) \\
(\mathrm{mEq} / \mathrm{l}) \\
(\mathrm{KAU} / 100 \mathrm{ml})\end{array}$ & $\begin{array}{c}7 \cdot 5 \pm 0 \cdot 5 \\
4 \cdot 4 \pm 0 \cdot 3 \\
6 \cdot 6 \pm 2 \cdot 7 \\
335 \pm 131 \\
507 \pm 157 \\
42 \pm 6 \\
5 \cdot 0 \pm 0 \cdot 2 \\
2 \cdot 7 \pm 0 \cdot 3 \\
17 \cdot 0 \pm 6\end{array}$ & $\begin{array}{c}7 \cdot 3 \pm 0 \cdot 4 \\
4 \cdot 4 \pm 0 \cdot 3 \\
4 \cdot 7 \pm 2 \cdot 5 \\
309 \pm 154 \\
470 \pm 172 \\
41 \pm 3 \\
4 \cdot 9 \pm 0 \cdot 3 \\
2 \cdot 4 \pm 0 \cdot 4 \\
20 \pm 8\end{array}$ & $\begin{array}{l}\text { NS } \\
\text { NS } \\
<0.01 \\
\text { NS } \\
\text { NS } \\
\text { NS } \\
\text { NS } \\
<0.001 \\
<0.05\end{array}$ \\
\hline
\end{tabular}

KAU, King-Armstrong units. NS, not significant. 
TABLB II

Serum hepatic enzymes in study 1

\begin{tabular}{|c|c|c|c|}
\hline & $\begin{array}{c}\text { Control group } \\
\text { (mean } \pm \text { SEM) (range) }\end{array}$ & $\begin{array}{l}\text { Anticonvulsant group } \\
\text { (mean } \pm \text { SEM) (range) }\end{array}$ & $\mathbf{P}$ \\
\hline $\begin{array}{l}\gamma \text {-Glutamyl transpeptidase (IU/L.) } \\
5^{\prime} \text { Nucleotidase (IU/1.) } \\
\text { Leucine aminopeptidase (IU/L.) } \\
\text { Glutamate-oxaloacetate transaminase (IU/1.) }\end{array}$ & $\begin{aligned} 7 \cdot 4 & \pm 0 \cdot 6(3-15) \\
5 \cdot 3 & \pm 0 \cdot 4(1 \cdot 5-8 \cdot 5) \\
24 \cdot 0 & \pm 1 \cdot 1(16-35) \\
9 \cdot 3 & \pm 0 \cdot 5(5-16 \cdot 5)\end{aligned}$ & $\begin{aligned} 24 \cdot 7 & \pm 2 \cdot 8(4-95) \\
7 \cdot 4 & \pm 0 \cdot 5(1 \cdot 5-16 \cdot 5) \\
28 \cdot 4 & \pm 1 \cdot 4(7-50) \\
8 \cdot 8 & \pm 0 \cdot 3(6-16 \cdot 5)\end{aligned}$ & $\begin{array}{l}<0.001 \\
<0.005 \\
<0.05 \\
\quad \text { NS }\end{array}$ \\
\hline
\end{tabular}

NS, not significant.

convulsants than in controls (Table II). The effect was greatest for $\gamma$-glutamyl transpeptidase (Fig. 3) and least for leucine aminopeptidase. There was no correlation between serum alkaline phosphatase and these three enzymes.

Study 2. Effect of treatment with $5 \mu \mathrm{g}(200$ IU) cholecalciferol daily (Table III). The mean values of serum phosphate and alkaline phosphatase were the same in children on anticonvulsants after they had been fed small doses of cholecalciferol or placebo. The values for serum calcium were slightly higher in study 2 than in study 1 , Comparison of results between study 1 and 2 (paired ' $t$ ' test) showed a small but significant positive difference in the mean values of serum alkaline phosphatase in the anticonvulsant group given cholecalciferol (serum alkaline phosphatase in study $1,22 \pm 7 \mathrm{KAU} ; 25 \pm 13$ in study $2, \mathrm{P}<0.05)$. This finding suggested that there might have been a sluggish response to the administration of cholecalciferol.

Radiology. 12 children had serum biochemical values suggestive of vitamin $D$ deficiency (phosphate $2 \mathrm{mEq} / \mathrm{l}$. or less; alkaline phosphatase $30 \mathrm{KAU} / 100$ $\mathrm{ml}$ or higher). 3 were in the control group and 9 were epileptic. The wrists of these 12 children were $x$-rayed and in 3 cases there was widening of the epiphyseal plates at the lower end of the radius

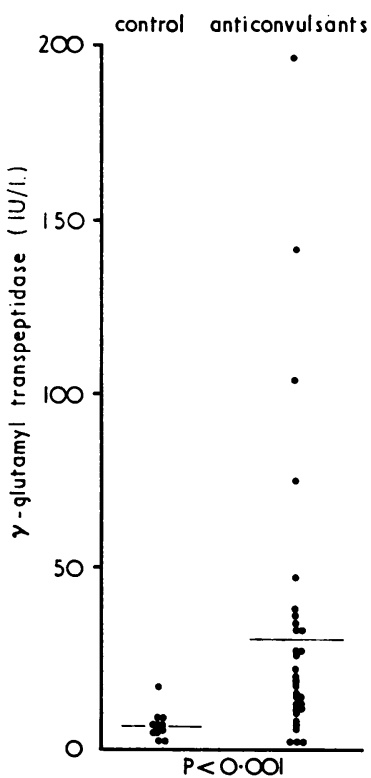

FIG. 3.- $\gamma$-Glutamyl transpeptidase activity in control children and children on anticonvulsant drugs.

and ulna and irregularity in metaphyseal ossification (Dr. F. H. Doyle). These 3 children, with radiological rickets, were all taking anticonvulsants and had received $5 \mu \mathrm{g}$ cholecalciferol daily for 12

TABLE III

Study 2. Serum calcium, phosphate, and alkaline phosphatase after treatment with cholecalciferol or placebo $($ mean $\pm S D)$

\begin{tabular}{|c|c|c|c|c|c|c|}
\hline & \multicolumn{3}{|c|}{ Control group } & \multicolumn{3}{|c|}{ Anticonvulsant group } \\
\hline & $\begin{array}{c}\text { Placebo } \\
(\text { no. }=17)\end{array}$ & $\begin{array}{c}\text { Cholecalciferol } \\
(\text { no. = 17) }\end{array}$ & $\mathbf{P}$ & $\begin{array}{c}\text { Placebo } \\
\text { (no. }=25)\end{array}$ & $\begin{array}{l}\text { Cholecalciferol } \\
(\text { no. = 27) }\end{array}$ & $\mathbf{P}$ \\
\hline $\begin{array}{l}\text { Calcium (mEq/l.) } \\
\text { Phosphate (mEq/l.) } \\
\text { Alkaline phosphatase } \\
\text { (King-Armstrong units) }\end{array}$ & $\begin{array}{c}5 \cdot 2 \pm 0 \cdot 2 \\
2 \cdot 7 \pm 0 \cdot 4 \\
18 \pm 7\end{array}$ & $\begin{array}{c}5 \cdot 2 \pm 0 \cdot 1 \\
2 \cdot 6 \pm 0 \cdot 3 \\
15 \pm 5\end{array}$ & $\begin{array}{l}\text { NS } \\
\text { NS } \\
\text { NS }\end{array}$ & $\begin{array}{c}5 \cdot 2 \pm 0 \cdot 2 \\
2 \cdot 5 \pm 0 \cdot 4 \\
20 \pm 7\end{array}$ & $\begin{array}{c}5 \cdot 1 \pm 0 \cdot 2 \\
2 \cdot 4 \pm 0 \cdot 5 \\
25 \pm 13\end{array}$ & $\begin{array}{l}\text { NS } \\
\text { NS } \\
<0.05\end{array}$ \\
\hline
\end{tabular}

NS, not significant. 
TABLE IV

Effect of $75 \mu \mathrm{g}$ cholecalciferol weekly for 12 weeks (paired ' $t$ ' tests) (mean $\pm S D$ )

\begin{tabular}{|c|c|c|c|c|c|c|}
\hline & \multicolumn{3}{|c|}{$\begin{array}{c}\text { Control group } \\
\text { (no supplement) } \\
\quad(\text { no. }=32)\end{array}$} & \multicolumn{3}{|c|}{$\begin{array}{c}\text { Anticonvulsant group } \\
\text { (cholecalciferol) } \\
(\text { no. }=33)\end{array}$} \\
\hline & Study 1 & Study 3 & $\mathbf{P}$ & Study 1 & Study 3 & $\mathbf{P}$ \\
\hline $\begin{array}{l}\text { Calcium }(\mathrm{mEq} / \mathrm{l} .) \\
\text { Phosphate }(\mathrm{mEq} / 1 .) \\
\text { Alkaline phosphatase }\end{array}$ & $\begin{array}{l}5 \cdot 0 \pm 0 \cdot 2 \\
2 \cdot 7 \pm 0 \cdot 3 \\
17 \pm 7\end{array}$ & $\begin{array}{l}5 \cdot 0 \pm 0 \cdot 2 \\
2 \cdot 7 \pm 0 \cdot 3 \\
19 \pm 8\end{array}$ & $\begin{array}{l}\text { NS } \\
\text { NS } \\
\text { NS }\end{array}$ & $\begin{array}{l}4 \cdot 9 \pm 0 \cdot 3 \\
2 \cdot 4 \pm 0 \cdot 4 \\
19 \pm 8\end{array}$ & $\begin{array}{c}4 \cdot 9 \pm 0 \cdot 2 \\
2 \cdot 6 \pm 0 \cdot 5 \\
23 \pm 14\end{array}$ & $\begin{aligned} & \text { NS } \\
< & 0.001 \\
< & 0.05\end{aligned}$ \\
\hline
\end{tabular}

NS, not significant.

weeks before the $x$-ray was taken. It was decided, therefore, to assess the effect of administering a larger dose of vitamin $\mathrm{D}$.

Study 3. Effect of treatment with $75 \mu \mathrm{g}$ (3000 IU) cholecalciferol per week. $75 \mu \mathrm{g}$ cholecalciferol was given each week to children taking anticonvulsants. After 12 weeks there were significant rises in serum phosphate and alkaline phosphatase (Table IV), and serum phosphate levels (mean $2 \cdot 6 \pm 0.5 \mathrm{mEq} / \mathrm{l}$.) were no longer significantly different from those of the control group (mean $2 \cdot 7 \pm 0 \cdot 3 \mathrm{mEq} / 1$.), which had not changed over the period of study. The early rise in serum alkaline phosphatase in response to vitamin $\mathrm{D}$ therapy is presumably a reflection of increased osteoblastic activity. The alkaline phosphatase would be expected to return to normal levels after total healing of the rickets (Morgan et al., 1965). $X$-rays of the wrists of the 3 children with radiological rickets now showed clear evidence of healing (Fig. 4).

\section{Discussion}

In this study we have shown that the nutritional status of children taking anticonvulsant drugs need not be seriously impaired and that it is possible to cure the tendency to develop rickets with a relatively small supplement of vitamin D. Other workers (Kruse, 1968; Richens and Rowe, 1970) have found a higher incidence of rickets than 3 cases out of 60 , and have shown that the mean serum calcium values are lower for a group of children taking anticonvulsants than controls. In the study reported here, values of serum phosphate were more sensitive than those of serum calcium in the detection of vitamin $\mathrm{D}$ deficiency, a finding which has been stressed previously (Kramer and Kanof, 1954; Fourman and Royer, 1968) and which will be missed in children if phosphate values are compared with the normal range for adults.

In this study the apparent dietary intake of 
deficiency does not occur until the intake falls to less than $70 \mathrm{IU} /$ day (Dent and Smith, 1969). The low incidence of rickets among the children in our study is almost certainly due to their good living conditions and frequent prolonged exposure to sunlight.

In the prevention of rickets it is important to administer calciferol or cholecalciferol in a dosage which will not lead to vitamin D intoxication as occurred in the 1950s in newborn infants (Report of the Fiftieth Anniversary Meeting of Pathological Society of Great Britain and Ireland, 1956), and in the 1960s in the treatment of vitamin D deficiency after partial gastrectomy (Anderson, Cooper, and Naylor, 1968). The administration of 200 IU (5 $\mu \mathrm{g})$ cholecalciferol/day appeared to produce a minimal improvement in children taking anticonvulsant drugs and it would need a long-term prospective study to determine whether or not this dose could be prophylactic. 3000 IU $(75 \mu \mathrm{g})$ cholecalciferol/week led to radiological evidence of healing in all 3 children with rickets and we had no cases of rickets resistant to treatment with vitamin D as described by Stamp et al. (1972), and Lifshitz and MacLaren (1973).

The finding that small physiological doses were insufficient to correct the biochemical evidence of vitamin $\mathrm{D}$ deficiency or to initiate the healing of rickets, suggests that the vitamin deficiency was not due solely to dietary deficiency. It is probable that anticonvulsants cause an increased metabolic requirement for vitamin $D$, which in some way is related to the inducing effect on hepatic microsomal enzymes (Conney, 1967). It has been shown previously that serum levels of $\gamma$-glutamyl transpeptidase may be raised in patients taking enzymeinducing drugs (Whitfield et al., 1973), and this has been confirmed. There was, however, no good correlation between the levels of circulating $\gamma$-glutamyl transpeptidase and the biochemical abnormalities related to a deficiency of vitamin $\mathrm{D}$. Serum levels of 5'nucleotidase and leucine aminopeptidase have previously been shown to be raised in a patient taking barbiturates (Greenwood, Prunty, and Silver, 1973). In the present study we have shown that these two enzymes are less sensitive indices of hepatic enzyme induction than $\gamma$-glutamyl transpeptidase. There was no effect on the serum levels of glutamate-oxaloacetate transaminase, an enzyme believed to be released from the cytoplasm of hepatic cells (Table II).

It has been postulated that enzyme induction leads to an enhanced catabolism and biliary excretion of vitamin D and its metabolites (Silver $e t$ al., 1972a, b). In Britain the population is exposed to relatively small amounts of ultraviolet light and thus the endogenous synthesis of vitamin $D$ is limited (Fourman and Royer, 1968). Recently it has been shown that the average dietary intake of vitamin D may not meet the metabolic requirement of normal growing children (Cooke et al., 1973). Epileptic children on long-term anticonvulsants are even more liable to develop vitamin $\mathrm{D}$ deficiency because of the effect of the drugs on vitamin $D$ metabolism. Such children should be given vitamin D supplements. $75 \mu \mathrm{g}$ (3000 IU) cholecalciferol weekly appears to be an adequate dose for adolescent children living under good conditions in southeast England.

The authors are grateful to Drs. G. Neale for help in planning this study, A. Breckenridge for advice on enzyme induction, A. V. Hoffbrand for haematological measurements, and F. H. Doyle for assessments of $x$-rays, all of the Royal Postgraduate Medical School.

This study would not have been possible without the co-operation of the consultants and nursing staff at Queen Mary's Hospital, and we thank Dr. J. Stern, clinical biochemist, Dr. B. Kirman, consultant psychiatrist, Mrs. A. E. Nicholas for dietary assessments, and Mr. J. Bensted for technical assistance.

This work was supported by a grant from the Medical Research Council.

\section{REFERENCES}

Anderson, D. C., Cooper, A. F., and Naylor, G. J. (1968). Vitamin $D$ intoxication, with hypernatraemia, potassium and water depletion, and mental depression. British Medical fournal, 4, 744.

Butler, T. C., and Waddell, W. J. (1956). Metabolic conversion of primidone (mysoline) to phenobarbital. Proceedings of the Society for Experimental Biology and Medicine, 93, 544.

Campbell, D. M. (1962). Determination of $5^{\prime}$-nucleotidase in blood serum. (Abst.) Biochemical fournal, 82, 34p.

Conney, A. H. (1967). Pharn acological implications of microsomal enzyme induction. Pharmacological Reviews, $19,317$.

Cooke, W. T., Swan, C. H. I., Asquith, P., Melikian, V., and McFeely, W. E. (1973). Serum alkaline phosphatase and rickets in urban schoolchildren. British Medical fournal, 1, 324.

Dent, C. E., Richens, A., Rowe, D. J. F., and Stamp, T. C. B. (1970). Osteomalacia with long-term anticonvulsant therapy in epilepsy. British Medical fournal, 4, 69.

Dent. C. E., and Smith, R. (1969). Nutritional osteomalacia. Quarterly fournal of Medicine, 38, 195.

Fourman, P., and Royer, P. (1968). Calcium Metabolism and the Bone, 2nd ed. Blackwell, Oxford.

Gough, K. R., Lloyd, O. C., and Wills, M. R. (1964). Nutritional osteomalacia. Lancet, $2,1261$.

Greenwood, R. H., Prunty, F. T. G., and Silver, J. (1973). Osteomalacia after prolonged glutethimide administration. British Medical fournal, 1, 643.

Hahn, T. J., Hendin, B. A., Scharp, C. R., and Haddad, J. G. (1972) Effect of chronic anticonvulsant therapy on serum 25-hydroxycalciferol levels in adults. New England fournal of Medicine, 287, 900.

Holmes, A. M., Enoch, B. A., Taylor, J. L., and Jones, M. E. (1973) Occult rickets and osteomalacia amongst the Asian immigrant population. Quarterly Fournal of Medicine, 42, 125.

Hunter, J., Maxwell, J. D., Stewart, D. A., Parsons, V., and Williams, R. (1971). Altered calcium metabolism in epileptic children on anticonvulsants. British Medical fournal, 4, 202.

Kramer, B., and Kanof, A. (1954). The Vitamins: Chemistry, Physiology, Pathology, Vol. II, p. 248. Ed. by W. H. Sebrell, Jr., and R. S. Harris. Academic Press, New York.

Kruse, R. (1968). Osteopathien bei antiepeileptischer Langzeittherapie (Vorläufige mitteilung). Monatsschrift für Kinderheilkunde, 116, 378. 
Lifshitz, F., and MacLaren, N. (1973). Vitamin $D_{2}$ (Vit. D) dihydrotachysterol (DHT) and 25-hydroxycholecalciferol (25 OHCC) treatment of vitamin D dependency rickets associated with anticonvulsants. (Abst.) Federation Proceedings, 32, 918.

McCance, R. A., and Widdowson, E. M. (1960). The Composition of Foods. Medical Research Council Special Report Series, No. 297, p. 170. H.M.S.O., London.

MacGee, J. (1970). Rapid determination of diphenylhydantoin in blood plasma by gas-liquid chromatography. Analytical Chemistry, 42, 421.

Morgan, D. B., Paterson, C. R., Woods, C. G., Pulvertaft, C. N., and Fourman, P. (1965). Osteomalacia after gastrectomy. A response to very small doses of vitamin D. Lancet, $2,1089$.

Moss, D. W., Shakespeare, M. J., and Thomas, D. M. (1972). Observations on the heat-stability of alkaline phosphatase isoenzymes in serum. Clinica Chimica Acta, 40, 35.

National Research Council (1958). Recommended daily dietary allowances. Food and Nutrition Board, Washington, D.C

Peters, T. J., Müller, M., and de Duve, C. (1972). Lysosomes of the arterial wall. I. Isolation and subcellular fractionation of cells from normal rabbit aorta. Fournal of Experimental Medicine, 136, 1117.

Report of the Fiftieth Anniversary Meeting of Pathological Society of Great Britain and Ireland (1956). Hypercalcaemia in infants and vitamin D. British Medical fournal, 2, 149.

Richens, A., and Rowe, D. J. F. (1970). Disturbance of calcium metabolism by anticonvulsant drugs. British Medical fournal, $4,73$.

Schmid, F. (1967). Osteopathien bei antiepileptischer dauerbehandlung. Fortschritte der Medizine, 8, 381.
Silver, J., Quill, H., Neale, G., and Thompson, G. R. (1972a) Effect of phenobarbitone-induction on the excretion of vitamin $D$ metabolites in bile. (Abst.) Clinical Science, 43, 4p.

Silver, J., Thompson, G. R., Neale, G., Cameron, J. D., Orme, M. Davies, D., and Breckenridge, A. (1972b). Increased rate of metabolism of vitamin $\mathrm{D}_{3}$ in phenobarbitone-induced rats. In Endocrinology, 1971. Proceedings of the 3rd International Symposium, 19-22fuly, 1971, London, p. 477. Ed. by S. Taylor. Heinemann, London.

Stamp, T. C. B., Round, J. M., Rowe, D. J. F., and Haddad, J. G. (1972). Plasma levels and therapeutic effect of 25-hydroxycholecalciferol in epileptic patients taking anticonvulsant drugs. British Medical fournal, 4, 9.

Stanbury, S. W., Mawer, E. B., Lumb, G. A., Hill, L. F., Holman, C. A., Jones, M., and Van Den Berg, C. J. (1972). Some aspects of vitamin D metabolism in man. In Endocrinology. Proceedings of the 3rd International Symposium, 19-22 fuly, 1971, p. 487. Ed. by S. Taylor. Heinemann, London.

Szasz, G. (1969). A kinetic photometric method for serum $\gamma$ glutamyl transpeptidase. Clinical Chemistry, 15, 124.

Whitfield, J. B., Moss, D. W., Neale, G., Orme, M., and Breckenridge, A. (1973). Changes in plasma gamma-glutamyl transpeptidase activity associated with alterations in drug metabolism in man. British Medical fournal, 1, 316.

Correspondence to Dr. J. Silver, Department of Medicine 'B', Hadassah University Hospital, Jerusalem, Israel. 